\title{
Influence of treatment with water-soluble CCB preservative on the physical-mechanical properties of brazilian tropical timber
}

\author{
Andréa de Souza Almeida ${ }^{a}{ }^{(*}$, Gabriel Criscuolo ${ }^{a}$, Tiago Hendrigo de Almeida ${ }^{a}$, André Luis \\ Christoforo $^{b}$, Francisco Antonio Rocco Lahr \\ ${ }^{a}$ Departamento de Ciência e Engenharia de Materiais, Universidade de São Paulo - USP, Av. \\ Trabalhador São-Carlense, 400, CEP 13566-590, São Carlos, SP, Brasil \\ ${ }^{b}$ Departamento de Engenharia Civil, Universidade Federal de Sao Carlos - UFSCar, Rodovia \\ Washington Luis, km 235 - SP310, CEP 13565-905, São Carlos, Brasil \\ ${ }^{C}$ Departamento de Estruturas, Universidade de São Paulo - USP, Av. Trabalhador São-Carlense, 400, \\ CEP 13566-590, São Carlos, SP, Brasil
}

Received: October 23, 2018; Revised: March 03, 2019; Accepted: October 16, 2019

\begin{abstract}
This aim of this work is to present an analysis of the influence of impregnation against biological demand, realized with saline solution of CCB (Chromated Copper Borate preservative) by vacuumpressure process, on physical-mechanical properties of tropical wood species Simarouba sp., Cedrelinga catenaeformis and Erisma uncinatum Warm. In theory, such process could increase the number of surface defects in wood pieces and reduce its strength properties. To investigate this influence, the complete species characterization was carried out in two conditions (without treatment and CCB treated wood). Tukey's multiple comparisons test (5\% significance level) was applied. In addition, scanning electron microscopy (SEM) photomicrographs were obtained with the energy dispersive spectroscopy (EDS) to investigate preservative presence at the cellular level. Results permitted to conclude that CCB impregnation process did not affect physical-mechanical properties of the studied species.
\end{abstract}

Keywords: Wood treatment; $C C B$ preservative; Physical-mechanical properties; Scanning electron microscopy (SEM).

\section{Introduction}

Wood is a renewable material with physical-mechanical properties that allow its use in various purposes, such as construction, the furniture industry, energy production, paper and pulp. In addition, it has a strong ecological appeal, if proper management is employed in plantation zones ${ }^{1,2}$. Besides, wood presents advantages when compared to other building materials, such as concrete and steel. Among them, it is possible to mention the beautiful appearance, high mechanical strength, easy workability and is a good thermal and electrical insulation ${ }^{2,3}$. As restriction, one may cite its susceptibility to xylophagous organisms, consequence of their biological origin which leads to moisture retention and, consequently, proliferation of biological organisms that induce its deterioration ${ }^{4-6}$.

When wood is outdoor exposed to environment without going through appropriate preservative treatment, its biodeterioration occurs ${ }^{7,8}$. Wood properties are changed due to physical, chemical, mechanical or biological agents, the latter being xylophagous organisms ${ }^{2,9}$. These organisms attack the natural polymers of wood cell walls, which act as sources of nutrition. Some fungi and termites have a wide range of enzymes capable to metabolize natural polymers and, consequently, can cause significant changes in wood

*e-mail: andreaalmeida@usp.br properties $^{10-12}$. Therefore, xylophagous organisms are able to contribute to drastic reduction of the values of strength of the wood, being factor of economic importance ${ }^{2,9}$.

To increase wood durability, several processes and chemicals have been developed ${ }^{13,14}$. Currently, water-soluble chemicals, are the most commonly used to such purpose. Wood treatment methods that employ such products are so-called chemical treatments ${ }^{14}$, fundamental to extend wood service life ${ }^{15,16}$.

Due to the controversy that water-soluble preservative Chromated Copper Arsenate (CCA), usual in Brazilian pressure treatment processes, pose risks to human health, arsenic of the CCA compound has been replaced by boron. So, Chromated Copper Borate (CCB) was raised, beginning to be marketed in Germany (early 1960s) as "Wolmanit CB" $17-19$. Borates popularity has grown once they are more environmentally friendly than CCA, but do not stick to wood as CCA and should not be used in places constantly wet. Unlike the CCA that concentrates wood cells walls, borate spreads into wood after under-pressure treatment, proportioning deeper penetration ${ }^{20}$.

Protection achieved through chemical preservatives has been shown to be essential in increasing durability of species with low natural resistance or that possess a high amount of sapwood, less permeable than core and more susceptible to biodeterioration. Treatment efficacy is assessed by penetration 
and retention achieved by preservatives in wood ${ }^{2}$. Choice of the most appropriate method depends on each species and on wood treated purpose $\mathrm{e}^{19,21}$.

Researches in matter of characterization of tropical wood species need to be further explored, since knowledge in this field is still incomplete, mainly due to growing demand for timber products and consequent the introduction of new fast growing tropical wood species, in recent years ${ }^{22-25}$. These species present medium to low density and must receive preservation treatment to ensure their durability in service. Thus, with the widespread application of tropical species in many countries, knowledge of their properties and recommended preservative treatments have become essential ${ }^{22,23}$.

Terezo et al. ${ }^{26}$ reported several studies investigating effects that water-soluble preservative treatments may exert on mechanical properties, in northern hemisphere. Such effects are directly related to pretreatment, treatment, post-treatment and their respective process parameters as: species; mechanical property; industrial or chemical type immunizing agent; retention; drying; size and class of material and among others. This shows a large number of involved variables and the needing to reach more precise results with research in this area, aiming also to quantify influence of chemical treatment on Brazilian tropical wood species.

In a context where hundreds of species have not yet been classified in Brazilian Amazon Forest, and lack technological information on low and medium density species are so $\mathrm{few}^{27}$, this work was developed. It presents an evaluation of CCB treatment process influence on physical-mechanical properties of three tropical essences: Simarouba sp., Cedrelinga catenaeformis and Erisma uncinatum Warm, commonly known as Caixeta (C20), Cedroarana (C30) and Cambará (C40), respectively. If this influence is significative, it will be necessary to adopt a new strength modification coefficient in timber structures design, based on the requirements of ABNT NBR 7190/9728.

\section{Experimental Procedures}

\subsection{Materials}

In this work, three species of Brazilian tropical timber were analyzed: Simarouba sp., Cedrelinga catenaeformis and Erisma uncinatum Warm, more commonly known as Caixeta (C20), Cedroarana (C30) and Cambará (C40) (Figure 1). These species are usual in construction and were chosen in an attempt to cover the three lower strength classes according to ABNT NBR7190/199728 prescriptions. These classes are related to batches purposing use timber with standardized properties, assisting in specie choice for structural design.

- $\quad$ Caixeta (C20)

In Brazil there are two species, Simarouba amara and Simarouba versicolor, both are called Caixeta. In this work $S$. amara was used, which is found in Amazonas. Caixeta wood does not have a good natural resistance to fungi and insects attack ${ }^{29}$.

\section{- $\quad$ Cedroarana (C30)}

Cedroarana (Cedrelinga catenaeformis) is a large tree, and its highest occurrence is in Amazonas, Acre and Pará States, mainly in the last one. It has moderate resistance to attack of rotting fungi and termites. Heartwood and sapwood are not easy to treat with water-soluble preservative products, even when treated under pressure ${ }^{29}$.

\section{- Cambará (C40)}

Also called Cedrinho, the scientific name of the Cambará is Erisma uncinatum Warm. It has occurrence of the Amazon region, especially in Pará. Its durability is low and with low resistance to xylophagous organisms. Sapwood and heartwood are easy to preserve when subjected to pressure treatments ${ }^{29}$.

\subsection{Methods}

Timber pieces used to carry out this work were CCBtreated through vacuum-pressure process, in autoclave, with 12 up $14 \mathrm{~atm}$, retention of $9.6 \mathrm{~kg}$ of preservative $/ \mathrm{m}^{3}$ of treated wood, in PREMA Tecnologia e Comércio Ltda in Rio Claro, Brazil. Table 1 shows formulation considered to be typical of $\mathrm{CCB}$, with $40 \%$ active ingredients relative to resulting salt dry mass.

\subsubsection{Physical-mechanical properties and application of Tukey's test}

Figure 2 shows timber pieces nominal dimensions that furnished the specimens to be tested. For each wood species, it was necessary to use twelve pieces of $16 \mathrm{~cm} \times 6 \mathrm{~cm} \times 150 \mathrm{~cm}$ for each treated section (no treatment; CCB-treated) to specimen preparation. Properties were determined taking into account recommendations of Annex B (Determination

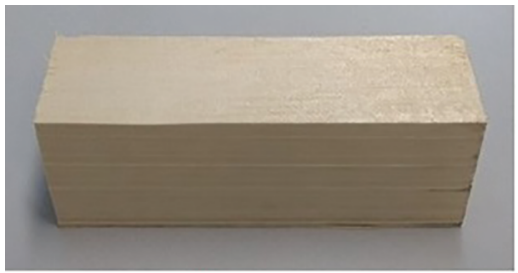

(a)

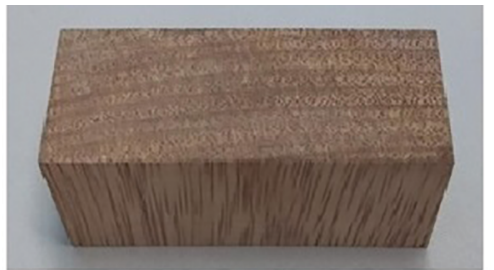

(b)

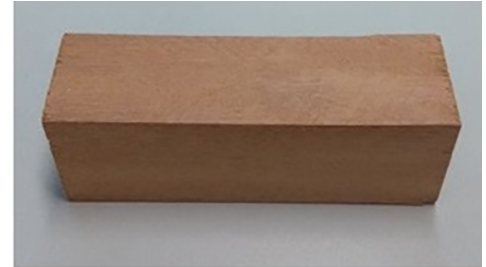

(c)

Figure 1. Specimens for the compression test: (a) Caixeta, (b) Cedroarana, and (c) Cambará. 
Table 1. Composition of CCB.

\begin{tabular}{cc}
\hline Compounds & Percentages (\%) \\
\hline $\mathrm{CuSO}_{4}$ & 35,8 \\
$\mathrm{H}_{3} \mathrm{BO}_{3}$ & 22,4 \\
$\mathrm{~K}_{2} \mathrm{Cr}_{2} \mathrm{O}_{7}$ & 38,5 \\
$\mathrm{NaHSO}_{4}$ & 2,1 \\
\hline
\end{tabular}

*Source: Lepage ${ }^{17}$.

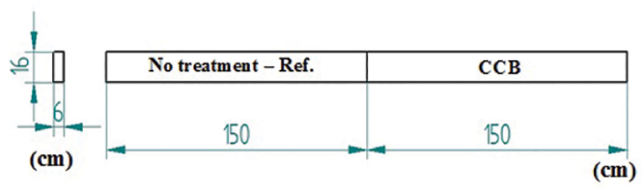

Figure 2. Withdrawal of the samples for the tests.

of wood properties for structural design), ABNT NBR 7190:1997: Timber Structures Design ${ }^{28}$.

Annex B provides the test methods for determination of properties, in view of the complete, minimum and simplified characterization of the wood, which are defined in main text of standard. For mechanical tests realization, it was used a AMSLER Universal Testing Machine, $250 \mathrm{kN}$ capacity. Toughness tests were carried out in a specific machine.

Firstly, complete characterization of untreated pieces was carried out and, an afterwards, of the CCB-treated ones. Strength and stiffness properties had their values corrected for standard reference moisture of $12 \%$ as established by ABNT NBR 7190/9728.

Table 2 presents values of the investigated mechanical properties, samples without preservative treatment (Ref) and CCB-treated. As twelve specimens were produced per species, type of test and by investigated experimental condition, 1008 determinations in total were made.

Influence of treatment factor [Tr] (without - Ref, CCB) on considered properties was evaluated using Tukey's test, at 5\% significance level. From Tukey test: A denotes experimental condition with the property highest mean value; B experimental condition associated with the second highest mean value and so on. Equal letters imply in treatments with statistically equivalent means.

\subsubsection{Scanning Electron Microscopy (SEM) and Energy Dispersive Spectroscopy (EDS)}

These tests were carried out only for Simarouba amara species because it is the most porous and, consequently, provide a better analysis of location and adhesion of the preservative solution in wood cells (lumen and walls).

SEM photomicrographs were obtained from a ZEISS LEO 440 (Cambridge, England) with OXFORD detector (model 7060), operating with $20 \mathrm{kV}$ electron beam, 2.82A current and 200pA probe. Samples were covered with $6 \mathrm{~nm}$ gold, in a Coating System BAL-TEC MED 020 metallizer (BAL-TEC, Liechtenstein), and kept in desiccator until analysis. Metallization conditions: chamber pressure $=$ $2,00 \times 10^{-2} \mathrm{mbar}$; current $=60 \mathrm{~mA}$; deposition rate $0.60 \mathrm{~nm} / \mathrm{s}$.

Energy dispersive analysis (EDS) was performed on an EDX LINK ANALYTICAL equipment (Isis System Series 300), with SiLi Pentafet detector, ATW II (Atmosphere Thin Window), resolution of $133 \mathrm{eV}$ at $5.9 \mathrm{keV}$ and $10 \mathrm{~mm}^{2}$ area, coupled to ZEISS LEO 440 Electronic Microscope. Costandard for calibration, $20 \mathrm{kV}$ electron beam, $25 \mathrm{~mm}$ focal length, $30 \%$ dead time, $2.82 \mathrm{~A}$ current and I probe of $2,5 \mathrm{nA}$.

\section{Results and Discussion}

\subsection{Physical-mechanical properties and application of Tukey's test}

In this topic, are presented the experimental average values obtained $(\bar{X})$, coefficients of variation $(\mathrm{Cv})$, and Tukey test results for physical and mechanical properties species

Table 2. Properties evaluated.

\begin{tabular}{cc}
\hline Abreviations & Property \\
\hline$\rho_{\mathrm{ap}}$ & Apparent density at $12 \%$ moisture \\
$\mathrm{f}_{\mathrm{c} 0}$ & Compressive strength parallel to the grain \\
$\mathrm{E}_{\mathrm{c} 0}$ & Modulus of elasticity in parallel directions to the grain \\
$\mathrm{f}_{\mathrm{c} 90}$ & Compressive strength in normal direction to the grain \\
$\mathrm{f}_{\mathrm{t} 0}$ & Tensile strength parallel to the grain \\
$\mathrm{E}_{\mathrm{t} 0}$ & Modulus of elasticity in tension parallel to the grain \\
$\mathrm{f}_{\mathrm{t} 90}$ & Tensile strength normal to the grain \\
$\mathrm{f}_{\mathrm{M}}$ & Conventional strength on static bending test \\
$\mathrm{E}_{\mathrm{M}}$ & Conventional modulus of elasticity on static bending test \\
$\mathrm{f}_{\mathrm{H} 0}$ & Hardness parallel to the grain \\
$\mathrm{f}_{\mathrm{H} 90}$ & Hardness normal to the grain \\
$\mathrm{f}_{\mathrm{v}}$ & Shear strength parallel to the grain \\
$\mathrm{f}_{\mathrm{s}}$ & Splitting strength \\
$\mathrm{W}$ & Toughness
\end{tabular}


investigated in conditions without preservative treatment (Ref) and CCB-treated.

\subsubsection{Caixeta}

Table 3 presents the mentioned properties of $S$. amara (Caixeta).

According to ABNT NBR 7190/199728 the maximum values for the coefficient of variation $(\mathrm{Cv})$, so that the characterization can be described as adequate, is $18 \%$ for strength to normal efforts $\left(\mathrm{f}_{\mathrm{t} 0}\right.$ e $\left.\mathrm{f}_{\mathrm{c} 0}\right)$, and $28 \%$ for tangential efforts $\left(f_{v}\right)$. Caixeta characterization for all treatment cases met these limits.

By Tukey's test, CCB preservative process significantly increased values of tensile strength parallel $\left(f_{t 0}\right)$ and normal $\left(f_{t 90}\right)$ to the grain, splitting strength $\left(f_{s}\right)$, shear strength parallel to the grain $\left(f_{v}\right)$ and toughness $(W)$. Preservation process did not influence values of the other properties.

Values of compressive strength parallel to grain, tensile strength normal to grain and conventional strength on static bending test were lightly different from those published by Institute for Technological Research (Instituto de Pesquisas Tecnológicas - IPT ${ }^{29}$. This can be explained by wood is a biological origin material, with certain variability of their physical and mechanical properties within same species depending on batches ${ }^{30}$.

No research has been found on complete characterization of $S$. amara species or eventual reductions in its properties due to preservative treatments. Therefore, no further comparisons will be possible.

\subsubsection{Cedroarana (C30)}

Table 4 presents mean values, coefficients of variation (Cv) and Tukey test results for the investigated properties of Cedrelinga catenaeformis (Cedroarana).
Only tensile strength parallel to grain exceeded CV limit stipulated by ABNT NBR $7190^{28}$. Considering that this limit is an average of the analyzed results through available batches it is perfectly possible to find values higher than it (and lower) without batches must be discarded.

As in case of Caixeta, it will not be possible to compare experimental mean values with those of literature, just because there is no research that about complete characterization of Caixeta and Cedroarana.

By Tukey test, CCB treatment process did not significantly affect mechanical properties of Cedroarana, but only splitting strength had its values increased significantly by chemical treatment, turning the properties of treated and untreated Cedroarana statistically equivalents.

\subsubsection{Cambará}

Table 5 shows mean values of literature for strength properties of Cambará and Table 6 shows mean values, coefficients of variation $(\mathrm{Cv})$ and Tukey test results for investigated properties of such essence.

According to Lahr et al. ${ }^{31}$ about complete characterization of Erisma uncinatum Warm, apparent density for this species at $12 \%$ moisture is $0.68 \mathrm{~g} / \mathrm{cm}^{3}$, very close to the values found for the untreated material and with CCB-treated pieces. By Tukey's test, CCB treatment process did did not affect significantly apparent density of Cambará.

Only CV calculated for tensile strength parallel to grain exceeded the limit stipulated by ABNT NBR $7190^{28}$. Strength in compression parallel to grain $\left(\mathrm{f}_{\mathrm{c} 0}\right)$ obtained in this work, for the two treatment conditions, were higher than that presented by Lahr et al. ${ }^{31}$. The same applies to strength in tension parallel to grain $\left(f_{t 0}\right)$, to hardness parallel to grain $\left(f_{H 0}\right)$, to conventional strength on static bending test $\left(f_{M}\right)$ and to toughness $(\mathrm{W})$.

Table 3. Mean experimental values, coefficients of variation $(\mathrm{Cv})$ and Tukey test results for the properties evaluated for $S$. amara (Caixeta).

\begin{tabular}{|c|c|c|c|c|}
\hline \multirow{2}{*}{ Properties } & \multicolumn{2}{|c|}{ Ref. } & \multicolumn{2}{|c|}{ With CCB } \\
\hline & $\bar{X}$ & $\mathrm{Cv}(\%)$ & $\bar{X}$ & $\mathrm{Cv}(\%)$ \\
\hline$\rho_{\text {ap }}\left(\mathrm{g} / \mathrm{cm}^{3}\right)$ & $0.33 \mathbf{A}$ & 2.67 & $0.34 \mathbf{A}$ & 5.85 \\
\hline $\mathrm{f}_{\mathrm{c} 0}(\mathrm{MPa})$ & $34.47 \mathbf{A}$ & 15.49 & $32.83 \mathbf{A}$ & 10.47 \\
\hline $\mathrm{f}_{\mathrm{c} 90}(\mathrm{MPa})$ & $7.20 \mathrm{~A}$ & 14.99 & $6.59 \mathbf{A}$ & 12.14 \\
\hline $\mathrm{f}_{\mathrm{t} 0}(\mathrm{MPa})$ & $49.48 \mathbf{A B}$ & 7.41 & $54.07 \mathrm{~A}$ & 14.02 \\
\hline $\mathrm{f}_{t 90}(\mathrm{MPa})$ & $2.46 \mathbf{A B}$ & 25.60 & $2.90 \mathrm{~A}$ & 23.81 \\
\hline $\mathrm{f}_{\mathrm{M}}(\mathrm{MPa})$ & $62.36 \mathrm{~A}$ & 15.03 & $64.56 \mathbf{A}$ & 13.69 \\
\hline $\mathrm{f}_{\mathrm{v}}(\mathrm{MPa})$ & $8.56 \mathbf{B}$ & 17.39 & $10.80 \mathbf{A}$ & 19.49 \\
\hline $\mathrm{f}_{\mathrm{s}}(\mathrm{MPa})$ & $0.40 \mathrm{~B}$ & 24.03 & $0.58 \mathrm{~A}$ & 29.53 \\
\hline $\mathrm{f}_{\mathrm{H} 0}(\mathrm{MPa})$ & $509.16 \mathbf{A}$ & 14.04 & $558.73 \mathbf{A}$ & 19.32 \\
\hline $\mathrm{f}_{\text {н90 }}(\mathrm{MPa})$ & $283.33 \mathbf{A}$ & 15.19 & $304.53 \mathbf{A}$ & 11.79 \\
\hline $\mathrm{E}_{\mathrm{c} 0}(\mathrm{MPa})$ & $7325 \mathbf{A}$ & 29.71 & 7346 A & 22.72 \\
\hline $\mathrm{E}_{\mathrm{t} 0}(\mathrm{MPa})$ & 9414 A & 7.02 & 8809 A & 13.94 \\
\hline $\mathrm{E}_{\mathrm{M}}(\mathrm{MPa})$ & $8858 \mathbf{A}$ & 17.85 & 9996 A & 17.23 \\
\hline W (N.m) & $15.37 \mathbf{B}$ & 22.11 & $26.29 \mathrm{~A}$ & 14.20 \\
\hline
\end{tabular}


Table 4. Mean experimental values, coefficients of variation $(\mathrm{Cv})$ and Tukey test results for the properties evaluated for Cedrelinga catenaeformis (Cedroarana).

\begin{tabular}{lcccc}
\hline \multirow{2}{*}{ Properties } & \multicolumn{2}{c}{ Ref. } & \multicolumn{2}{c}{ With CCB } \\
\cline { 2 - 5 } & $\bar{X}$ & $\mathbf{C v}(\mathbf{\%})$ & $\bar{X}$ & $\mathbf{C v}(\mathbf{\%})$ \\
\hline$\rho_{\mathrm{ap}}\left(\mathrm{g} / \mathrm{cm}^{3}\right)$ & $0.54 \mathbf{A}$ & 10.24 & $39.72 \mathbf{A}$ & 2.89 \\
$\mathrm{f}_{\mathrm{c} 0}(\mathrm{MPa})$ & $41.36 \mathbf{A}$ & 15.49 & $4.28 \mathbf{A}$ & 10.47 \\
$\mathrm{f}_{\mathrm{c} 90}(\mathrm{MPa})$ & $4.54 \mathbf{A}$ & 7.86 & $68.84 \mathbf{A}$ & 3.17 \\
$\mathrm{f}_{\mathrm{t} 0}(\mathrm{MPa})$ & $67.20 \mathbf{A}$ & 30.16 & $4.68 \mathbf{A}$ & 33.05 \\
$\mathrm{f}_{\mathrm{t} 90}(\mathrm{MPa})$ & $4.35 \mathbf{A}$ & 23.55 & $67.65 \mathbf{A}$ & 24.39 \\
$\mathrm{f}_{\mathrm{M}}(\mathrm{MPa})$ & $71.43 \mathbf{A}$ & 34.13 & $11.82 \mathbf{A}$ & 20.37 \\
$\mathrm{f}_{\mathrm{v}}(\mathrm{MPa})$ & $10.44 \mathbf{A}$ & 21.21 & $0.68 \mathbf{A}$ & 10.88 \\
$\mathrm{f}_{\mathrm{s}}(\mathrm{MPa})$ & $0.51 \mathbf{B}$ & 16.77 & $561.47 \mathbf{A}$ & 30.00 \\
$\mathrm{f}_{\mathrm{H} 0}(\mathrm{MPa})$ & $508.98 \mathbf{A}$ & 29.43 & $389.11 \mathbf{A}$ & 36.29 \\
$\mathrm{f}_{\mathrm{H} 90}(\mathrm{MPa})$ & $346.06 \mathbf{A}$ & 29.67 & $8926 \mathbf{A}$ & 18.05 \\
$\mathrm{E}_{\mathrm{c} 0}(\mathrm{MPa})$ & $9352 \mathbf{A}$ & 28.20 & $8501 \mathbf{A}$ & 26.32 \\
$\mathrm{E}_{\mathrm{t} 0}(\mathrm{MPa})$ & $7527 \mathbf{A}$ & 16.62 & $10770 \mathbf{A}$ & 12.25 \\
$\mathrm{E}_{\mathrm{M}}(\mathrm{MPa})$ & $11048 \mathbf{A}$ & 26.49 & $67.95 \mathbf{A}$ & 22.68 \\
$\mathrm{~W}(\mathrm{~N} . \mathrm{m})$ & $62.85 \mathbf{A}$ & 49.34 & & \\
\hline
\end{tabular}

Table 5. Mean values of the literatuwre for the strength and fracture toughness properties of Erisma uncinatum Warm (Cambará).

\begin{tabular}{lcccccccc}
\hline Properties & $\begin{array}{c}\mathrm{f}_{\mathrm{c} 0} \\
(\mathrm{MPa})\end{array}$ & $\begin{array}{c}\mathrm{f}_{\mathrm{c} 90} \\
(\mathrm{MPa})\end{array}$ & $\begin{array}{c}\mathrm{f}_{\mathrm{t} 0} \\
(\mathrm{MPa})\end{array}$ & $\begin{array}{c}\mathrm{f}_{\mathrm{t} 90} \\
(\mathrm{MPa})\end{array}$ & $\begin{array}{c}\mathrm{f}_{\mathrm{M}} \\
(\mathrm{MPa})\end{array}$ & $\begin{array}{c}\mathrm{f}_{\mathrm{v}} \\
(\mathrm{MPa})\end{array}$ & $\begin{array}{c}\mathrm{f}_{\mathrm{s}} \\
(\mathrm{MPa})\end{array}$ & $\begin{array}{c}\mathrm{W} \\
(\mathrm{N} . \mathrm{m})\end{array}$ \\
\hline$\overline{\boldsymbol{X}}$ & 34 & 7.0 & 45 & 4.9 & 63 & 14 & 0.8 & 33.39 \\
\hline Properties & & $\begin{array}{c}\mathrm{E}_{\mathrm{c} 0} \\
(\mathrm{MPa})\end{array}$ & $\begin{array}{c}\mathrm{E}_{\mathrm{t} 0} \\
(\mathrm{MPa})\end{array}$ & $\begin{array}{c}\mathrm{E}_{\mathrm{M}} \\
(\mathrm{MPa})\end{array}$ & $\begin{array}{c}\rho_{\mathrm{ap}} \\
\left(\mathrm{g} / \mathrm{cm}^{3}\right)\end{array}$ & $\begin{array}{c}\mathrm{f}_{\mathrm{H} 0} \\
(\mathrm{MPa})\end{array}$ & $\begin{array}{c}\mathrm{f}_{\mathrm{H} 90} \\
(\mathrm{MPa})\end{array}$ \\
\hline$\overline{\boldsymbol{X}}$ & 12967 & 12764 & 12376 & 0.68 & 51 & 67 \\
\hline
\end{tabular}

Table 6. Mean experimental values, coefficients of variation $(\mathrm{Cv})$ and Tukey test results for the properties evaluated for Erisma uncinatum Warm (Cambará).

\begin{tabular}{|c|c|c|c|c|}
\hline \multirow{2}{*}{ Properties } & \multicolumn{2}{|c|}{ Ref. } & \multicolumn{2}{|c|}{ With CCB } \\
\hline & $\bar{X}$ & $\mathrm{Cv}(\%)$ & $\bar{X}$ & Cv (\%) \\
\hline$\rho_{\text {ap }}\left(\mathrm{g} / \mathrm{cm}^{3}\right)$ & $0.73 \mathrm{~A}$ & 9.89 & $0.72 \mathrm{~A}$ & 5.03 \\
\hline $\mathrm{f}_{\mathrm{c} 0}(\mathrm{MPa})$ & $70.54 \mathbf{A}$ & 14.99 & $65.58 \mathrm{~A}$ & 11.00 \\
\hline $\mathrm{f}_{\mathrm{c} 90}(\mathrm{MPa})$ & $7.20 \mathrm{~A}$ & 15.06 & $6.35 \mathrm{~A}$ & 12.77 \\
\hline $\mathrm{f}_{\mathrm{t} 0}(\mathrm{MPa})$ & $68.22 \mathrm{~A}$ & 32.10 & $73.19 \mathrm{~A}$ & 32.70 \\
\hline $\mathrm{f}_{\mathrm{t} 90}(\mathrm{MPa})$ & $2.62 \mathrm{~A}$ & 23.60 & $1.82 \mathrm{~B}$ & 36.36 \\
\hline $\mathrm{f}_{\mathrm{M}}(\mathrm{MPa})$ & $97.06 \mathbf{A}$ & 19.58 & $93.92 \mathbf{A}$ & 11.96 \\
\hline $\mathrm{f}_{\mathrm{v}}(\mathrm{MPa})$ & $12.48 \mathrm{~A}$ & 18.02 & $11.44 \mathbf{A}$ & 21.00 \\
\hline $\mathrm{f}_{\mathrm{s}}(\mathrm{MPa})$ & $0.44 \mathbf{A}$ & 17.80 & $0.26 \mathbf{B}$ & 28.16 \\
\hline $\mathrm{f}_{\mathrm{H} 0}(\mathrm{MPa})$ & $79.58 \mathbf{A}$ & 10.42 & $87.92 \mathbf{A}$ & 5.73 \\
\hline $\mathrm{f}_{\mathrm{H} 90}(\mathrm{MPa})$ & $51.50 \mathrm{~A}$ & 9.84 & $53.33 \mathbf{A}$ & 8.81 \\
\hline $\mathrm{E}_{\mathrm{c} 0}(\mathrm{MPa})$ & 14403 A & 20.30 & $13316 \mathbf{A}$ & 26.63 \\
\hline $\mathrm{E}_{\mathrm{t} 0}(\mathrm{MPa})$ & 13611 A & 22.31 & 13963 A & 24.11 \\
\hline $\mathrm{E}_{\mathrm{M}}(\mathrm{MPa})$ & $15601 \mathrm{~A}$ & 24.88 & 14689 A & 17.88 \\
\hline W (N.m) & $55.24 \mathbf{A}$ & 23.42 & 44.93 B & 13.85 \\
\hline
\end{tabular}


Strength normal to grain $\left(f_{t 90}\right)$, shear strength $\left(f_{v}\right)$, hardness normal to grain $\left(\mathrm{f}_{\mathrm{H} 90}\right)$ and splitting strength (fs), obtained in this work, were slightly lower than those in Table 5. Strength in compression normal to grain $\left(f_{c 90}\right)$, obtained for the two treatment conditions, was very close to literature values.

Tukey test showed that CCB preservative process significantly reduced strength in tension normal to grain, splitting and toughness, and did not significantly affect the other properties of Cambará woods. This species has higher density and greater difficulty of impregnation of chemical preservative solution. Decreases in values of those properties can be related to the heterogeneity of the characteristics of the batch analyzed.

Values obtained for modulus of elasticity were higher than those presented in Table 5. By Tukey test, the CCB preservative did not significantly decrease stiffness values of Cambará. No further research was found that included complete characterization of Erisma uncinatum Warm species and no researches that addressed influence of impregnation against biological demand on physical-mechanical properties of any wood species analyzed in this study.

\subsection{Scanning Electron Microscopy (SEM) and Energy Dispersive Spectroscopy (EDS)}

Figure 3 shows a SEM micrograph of Caixeta, without treatment, and Figure 4 shows a SEM micrograph from a crude surface where CCB preservative was applied as a

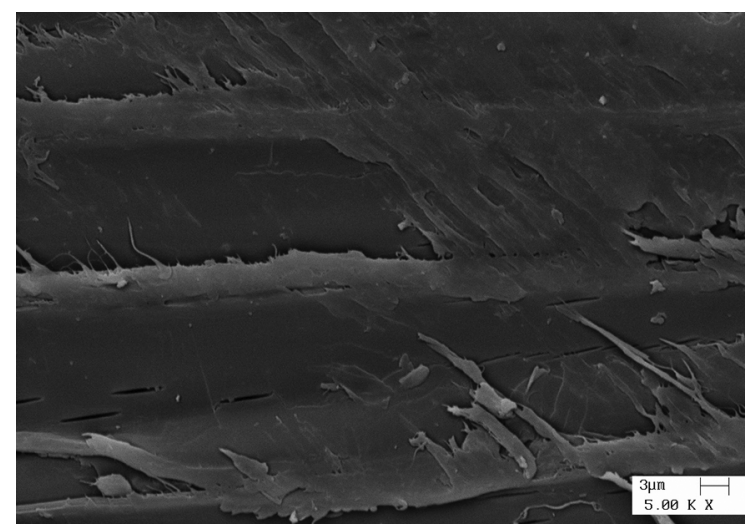

Figure 3. SEM micrography with 5000x magnification of Caixeta wood cells without treatment.

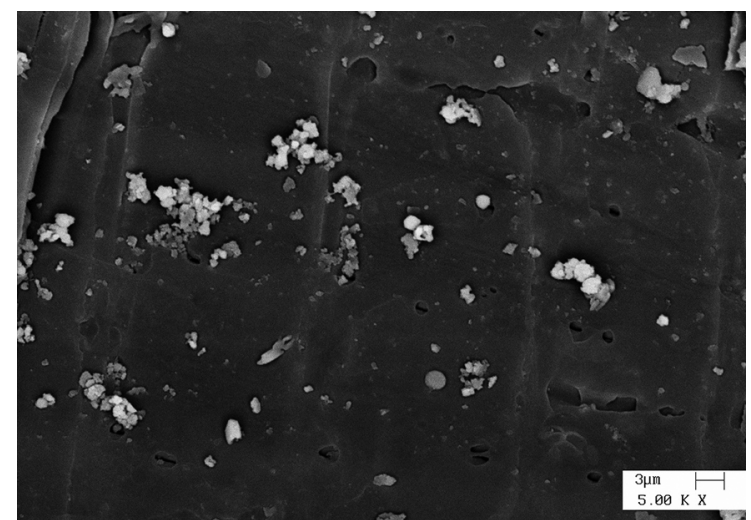

Figure 4. SEM micrography with 5000x magnification of Caixeta wood cells with CCB. water-diluted saline solution. As a surface in its raw state, SEM analysis was performed in a punctual way, choosing the region where we had the best visualization of cells and crystals incorporation in then.

It's possible to distinguish crystals dispersed in lumen. Such crystals are detached in relation to wood components due to the filter used in test, which make them lighter indicating metallic elements presence.

This image is composed of regions where lighter points contrast with darker regions. In order to investigate where the elements that make up preservative are found, EDS analysis was done in a region with low concentration of light points and a region with high concentration of clear points. Therefore, it was possible to verify that in second region a greater concentration of elements that composed CCB preservative was observed. With this observation and taking into account crystalline geometry of the light points, we can say that they are crystals. Thus, an analysis was performed on a crystal of greater area and higher concentrations of the elements present in preservative were obtained, as shown by EDS spectrum (Figure 5).

Crystals appear inside lumen, which is compatible with literature that cites $\mathrm{CCB}$ does not adhere to cell walls like CCA. So, Chromated Copper Borate has a lower leaching resistance and is more suitable for wood that will not contact water.

Concentrations of other elements, such as potassium, calcium, oxygen and carbon (highest peak) appearing in EDS spectrum are related to wood own composition and were already expected. Chlorine appears as an impurity of the substance used to wash tanks (autoclave) prior to preservation procedures with preservatives. Gold appears due to sample metallization by a conducting element. Sodium appears in spectrum because it is part of CCB typical composition, as shown in Table 1.

Due to equipment limitation, Boron element, because of its low molecular weight and atomic number (5), could not be detected. Therefore, analyzes were focused on the other elements that made up CCB. Preservative adhesion to the lumen was not enough to modify physical and mechanical properties, since preservative process was not aggressive.

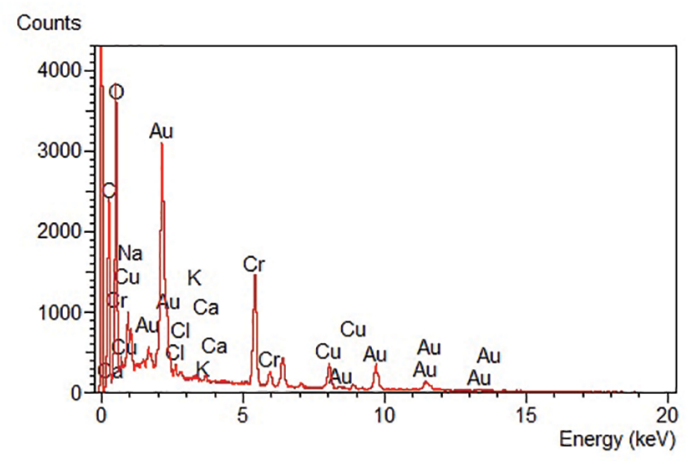

Figure 5. EDS spectrum of the cellular structure after treatment with CCB. 


\section{Conclusions}

It is concluded that $\mathrm{CCB}$ preservation process did not significantly decrease physical-mechanical properties of the three evaluated wood species, in some cases even increased their values. Even the treatment process involving drastic variations in temperature and pressure, which could cause surface cracks in wood its characteristics remained equivalent, without any structural damage.

As it was not confirmed the influence, it will not be necessary to adopt a new coefficient of modification of strengths, in timber structural design based on the requirements of ABNT NBR 7190.

Considering the context in which this research was developed, it remains as suggestion the continuity of this work for more tropical species for each class of strength defined by ABNT NBR 7190/1997 and with various types of chemical treatments, since different levels of impregnation and chemical reactions of fixation can be reached within each species.

\section{Acknowledgments}

This study was financed in part by the Coordenação de Aperfeiçoamento de Pessoal de Nível Superior - Brasil (CAPES) - Finance Code 001. For all the provided support, the authors thank the CAPES.

We thank the Wood and Timber Structes Laboratory (LaMEM), Department of Structural Engineering (SET), School of Engineering of Sao Carlos (EESC), University of São Paulo, where physical-mechanical tests were performed, and to the Central of Instrumental Chemical Analysis of the Institute of Chemistry of São Carlos (CAQI/IQSC/ USP) by the preparation of SEM and EDS tests.

\section{References}

1. Assagra YAO, Altafim RAP, da Silva FR, Basso HC, Lahr FAR, Altafim RAC. Laminated composite based on polyester geotextile fibers and polyurethane resin for coating wood structures. Materials Research. 2013;16(5):1140-1147. DOI: http://dx.doi.org/10.1590/s1516-14392013005000100

2. da Silveira AG, Baldin T, Vidrano BRA, Santini EJ, Trevisan R, Talgatii M. Quality of Hovenia dulcis thunb round fence posts submitted to preservative treatment. Floresta. 2018;48(1):59-66. DOI: http://dx.doi.org/10.5380/rf.v48i1.50118

3. Vidal JM, Evangelista WV, Silva JC, Jankowsky IP. Preservação de madeiras no Brasil: histórico, cenário atual e tendências. Ciência Florestal. 2015;25(1):257-271. DOI: http://dx.doi. org/10.1590/1980-509820152505257

4. Mohan D, Shi J, Nicholas DD, Pittman CU Jr, Steele PH, Cooper JE. Fungicidal values of bio-oils and their lignin-rich fractions obtained from wood/bark fast pyrolysis. Chemosfere. 2008;71(3):456-465. DOI: https://doi.org/10.1016/j. chemosphere.2007.10.049
5. Temiz A, Alma MH, Terziev N, Palanti S, Feci E. Efficiency of Bio-Oil Against Wood Destroying Organisms. Journal of Biobased Materials and Bioenergy. 2010;4(4):317-323. DOI: http://dx.doi.org/10.1166/jbmb.2010.1092

6. Temiz A, Akbas S, Panov D, Terziev N, Alma MH, Parlak S, et al. Chemical Composition and Efficiency of Bio-Oil Obtained from Giant Cane (Arundo donax L.) as a Wood Preservative. BioResources. 2013;8(2):2084-2098.

7. Williams RS. Weathering of Wood. In: Rowell RM, ed. Handbook of Wood Chemistry and Wood Composites. Boca Raton: CRC Press; 2005. p. 139-185.

8. Oberhofnerová E, Artenová K, Holeček T, BorůvkaV, Bomba J. Determination of Correlation between Destructive and Nondestructive Test Methods Applied on Modified Wood Exposed To Natural Weatering. BioResources. 2016;11(2):5155-5168. DOI: http://dx.doi.org/10.15376/biores.11.2.5155-5168

9. Milani CJ, Kripka MA. A Identificação de Patologias em Pontes de Madeira: Diagnóstico Realizado no Sistema Viário do Município de Pato Branco - Paraná. Revista Eletrônica de Engenharia Civil. 2012;4(1):23-33. DOI: https://doi.org/10.5216/ reec.v4i1.17726

10. Oliveira AMF, Lelis AT, Lepage ES, Lopes GAC, Oliveira LCS, Cañedo MD, et al. Agentes destruidores da madeira. In: Lepage ES, ed. Manual de Preservação de Madeiras. São Paulo: IPT; 1986. p. $99-278$.

11. Zabel RA, Morrell JJ. Wood Microbiology: Decay and its Preservation. San Diego: Academic Press; 1992. 474 p.

12. Ziglio AC, Gonçalves D. On the use of capsaicin as a natural preservative against fungal attack on Pinus sp. and Hymenaea sp. woods. Materials Research. 2014;17(1):271-274. DOI: http://dx.doi.org/10.1590/s1516-14392013005000141

13. de Cademartori PHG, Schneid E, Gatto DA, Beltrame R, Stangerlin DM. Modification of static bending strength properties of Eucalyptus grandis heat-treated wood. Materials Research. 2012;15(6):922-927. DOI: http://dx.doi.org/10.1590/s151614392012005000136

14. Boschetti WTN, Vieira DM, Moulin JC, Lopes DJV, Paes JB, Carvalho AMML. Preservative treatment of fence posts evaluation through photocolorimetry segmentation performance. Revista Árvore. 2016;40(4):731-739. DOI: http://dx.doi. org/10.1590/0100-67622016000400017

15. Magalhães WLE, Mattos BD, Missio AL. Field testing of CCAtreated Brazilian spotted gum. International Biodeterioration \& Biodegradation. 2012;74:124-128. DOI: https://doi.org/10.1016/j. ibiod.2012.05.024

16. Mattos BD, Gatto DA, de Cademartori PHG, Stangerlin DM, Beltrame R. Durabilidade a campo da madeira de três espécies de Eucalyptus tratadas por imersão simples. Revista Brasileira de Ciências Agrárias. 2013;8(4):648-655. DOI: http://dx.doi. org/10.5039/agraria.v8i4a3050

17. Lepage ES. Preservativos e sistemas preservativos. In: Lepage ES, ed. Manual de preservação de madeiras. São Paulo: IPT; 1986. p. 279-314. 
18. Richardson BA. Wood Preservation. London: E \& FN Spon; 1993. $226 \mathrm{p}$.

19. Ramos EIC, Paes JB, de Farias Sobrinho W, dos Santos JGC. Eficiência do CCB na resistência da madeira de algaroba (Prosopis juliflora (Sw.) D.C.) em ensaio de apodrecimento acelerado. Revista Árvore. 2006;30(5):811-820. DOI: http:// dx.doi.org/10.1590/S0100-67622006000500015

20. Morais A. Produtos para tratar madeira previnem perdas. Revista da Madeira. 2008;(117). Available from: <http://www. remade.com.br/br/revistadamadeira_materia.php?num $=1332 \&$ subject $=$ Preservantes $\&$ title $=$ Produtos $\% 20$ para $\% 20$ tratar $\% 20$ madeira $\% 20$ previnem $\% 20$ perdas $>$.

21. Santini EJ. Biodeterioração e preservação da madeira. Santa Maria: CEPEF/FATEC; 1988. 125 p.

22. Darmawan W, Rahayu I, Nandika D, Marchal R. The Importance of Extractives and Abrasives Wood Material on the Wearing of Cutting Tools. BioResources. 2012;7(4):4715-4729.

23. Jankowska A, Drożdżek M, Sarnowisk P, Horodeński J. Effect of Extractives on the Equilibrium Moisture Content and Shrinkage of Selected Tropical Wood Species. BioResources. 2017;12(1):597607. DOI: http://dx.doi.org/10.15376/biores.12.1.597-607

24. Pinzón Moreno DD, Saron C. Low-density polyethylene waste/ recycled wood composites. Composite Structures. 2017;176:11521157. DOI: https://doi.org/10.1016/j.compstruct.2017.05.076

25. Silva MR, Pinheiro RV, Christoforo AL, Panzera TH, Lahr FAR. Hybrid Sandwich Particleboard Made with Sugarcane, Pínus Taeda Thermally Treated and Malva Fibre from Amazon. Materials Research. 2017;21(1):e20170724. DOI: http://dx.doi. org/10.1590/1980-5373-mr-2017-0724
26. Terezo, RF, Neto JPR, Aguiar OJR. Influências de preservantes hidrossolúveis na resistência mecânica da madeira. Revista da Madeira. 2005;89.

27. ter Steege H, Vaessen RW, Cárdenas-López D, Sabatier D, Antonelli A, de Oliveira SM, et al. The discovery of the Amazonian tree flora with an update checklist of all known tree taxa. Scientific Reports. 2016;6:29549. DOI: http://dx.doi. org/10.1038/srep29549

28. Associação Brasileira de Normas Técnicas - ABNT. NBR 7190: Projeto de Estruturas de Madeira. Rio de Janeiro: ABNT; 1997. $107 \mathrm{p}$.

29. Instituto de Pesquisas Tecnológicas - IPT [Internet]. Wood information. Available from: http://www.ipt.br/consultas_online/ informacoes_sobre_madeira/busca $>$. Access in: 15/3/2017.

30. Segundinho PGA, Gonçalves FG, Gava GC, Tinti VP, Alves SD, Regazzi AJ. Eficiência da colagem de madeira tratada de Eucalyptus cloeziana F. Muell para produção de madeira laminada colada (MLC). Matéria (Rio de Janeiro). 2017;22(2):e11808. DOI: http://dx.doi.org/10.1590/s1517-707620170002.0140

31. Lahr FAR, Arroyo FN, Almeida TH, Almeida Filho FM, Mendes IS, Christoforo AL. Full characterization of Erisma uncinatum Warm wood specie. International Journal of Materials Engineering. 2016;6(5):147-150. DOI: http://dx.doi. org/10.5923/j.ijme.20160605.01 